\title{
The Mechanism by which Chronic Myeloid Leukemia Responds to Interferon- $\alpha$ Treatment
}

\author{
Emad Y. Moawad \\ Dept. of Engineering, Ain Shams University, Cairo, Egypt \\ *Corresponding Author: emadmoawad@hotmail.com
}

Copyright (C) 2013 Horizon Research Publishing All rights reserved.

\begin{abstract}
The goal of this work is to determine the mechanism by which addition of interferon- $\alpha$ (IFN- $\alpha$ ) to Dendritic Cells (DC) grown from Chronic Myeloid Leukemia (CML) patients improves its capacity to stimulate $\mathrm{T}$-lymphocyte responses, and decreases the proportion of bcr-abl positive DC. Bone marrow samples were obtained from six patients with CML and six normal donors to prepare mononuclear cells. T lymphocytes were removed, cultured without IFN- $\alpha$ (control sample) and with IFN- $\alpha$ doses of $5,50,250$, and $500 \mathrm{U} / \mathrm{mL}$. After a culture period of 14 days, DC were harvested and added to freshly allogeneic $\mathrm{T}$ cells by a ratio 1:10 for Mixed Lymphocyte Reaction (MLR) assay to identify energy of those mixed cultures $\left(\mathrm{E}_{\mathrm{MLR}}\right)$. Fluorescence in situ hybridization (FISH) was performed to quantify the frequency of bcr-abl in fresh samples from newly diagnosed CML patient with cultured DC without IFN- $\alpha$ and with IFN- $\alpha$ dose of $250 \mathrm{U} / \mathrm{mL}$. Variations in $\mathrm{E}_{\mathrm{MLR}}$ of mixed cultures were attributed to each of the difference in energy of the cultured DC (EDC) obtained from IFN- $\alpha$ doses, and either of rising the histologic grade (HG) of those cultures due to cell cycle arrest (ECCA) that cause treatment failure or reducing HG due to energy released by the loss of mitochondrial membrane potential ( $\Psi_{\text {mito }}$ ) activating apoptosis in bcr-abl positive cells. Percentage of decrease in bcr-abl positive DC in FISH analysis was $100 \%$ identical to that in each of EDC and $\Psi_{\text {mito }}(\mathrm{p} \leq 0.001)$. Patient-specific approaches that account for $\mathrm{HG}$ variations should enable more accurate dose estimates. IFN- $\alpha$ therapy is an energy balance process in which CML cells respond according to the mechanism of the following model:
\end{abstract}

$$
\begin{array}{r}
\mathrm{E}_{\mathrm{MLR}}=\mathrm{H}_{\mathrm{G}}+\mathrm{E}_{\mathrm{DC}} \text { \& } \begin{array}{r}
\mathrm{ECCA} \text { or } \\
\Psi_{\text {mito }}=\mathrm{Abs}
\end{array} \\
\text { (HG.Control - HG). }
\end{array}
$$

Keywords Dendritic cells; IFN- $\alpha$; Histologic grade; bcr/abl oncogene; Apoptosis; Mitochondria

\section{Introduction}

Chronic Myeloid Leukemia (CML) is a hematological malignancy its diagnosis is based on the histopathologic findings in the peripheral blood, characterized by the presence of the genetic aberration known by Philadelphia (Ph1) chromosome in Bone Marrow (BM) cells $[1,2]$. The chromosome results from a reciprocal translocation between chromosomes 9 and 22, which forms the chimerical bcr-abl oncogene [3]. The protein product shows an elevated tyrosine kinase activity when compared to normal c-Abl protein [4]. Bcr/abl decreases gradually the sensitivity of malignant cells to apoptotic stimuli until apoptosis prevention providing a survival advantage facilitating the outgrowth of malignant clones as commonly shared by cancer cells $[5,6]$. Dendritic cells (DC) have been shown responsible for the initiation of immune responses, able to stimulate $\mathrm{T}$ cells with specific activity against CML cells [7-10]. This function may be favorably affected by biologic immune response modifiers such as Interferon- $\alpha$ (IFN- $\alpha$ ) [11-13]. The role of IFN- $\alpha$ in differentiation and activity of monocyte-derived DC from CML patients was investigated and confirmed [14]. Cytogenetic analysis to IFN- $\alpha$ therapy revealed that IFN induces DC differentiation, cell-cycle arrest (CCA), and/or apoptosis which play roles in the compromised survival of the malignant cells [15]. In addition IFN- $\alpha$ has a powerful capacity to cause a sustainable elimination or suppress selectively cells bearing the Philadelphia chromosome, resulting in partial or complete restoration of the normal clone [16]. But despite of many years of current use of IFN$\alpha$ in CML patients and other malignancies, the mechanisms of the antitumor action of these cytokines are still a matter of debate. Yet the precise mechanism of action of IFN- $\alpha$ in the treatment of such diseases is not fully understood despite many advances have been made in the characterization of the physicochemical and diverse biological properties of this highly pleiotropic cytokine [17, 18]. Several studies described the significant effects of IFN$\alpha$ on enhancing stimulatory capacity of DC generated from CML patients in allogeneic Mixed Lymphocyte Reaction (MLR) to near normal levels $[17,18]$. Further analysis is required to determine whether the malignant cells are completely eliminated or only suppressed, besides explaining the reason of variations in patients' responses to 
IFN- $\alpha$ therapy [19]. Since alterations induced by bcr/abl decrease the ability to activate apoptosis resisting the anticancer drugs like IFN- $\alpha$, then one way that IFN's anti-CML response against such resistance to compromise the survival of the malignant CML cell is to induce apoptosis by down regulating the expression of bcr/abl fusion that could also play a role in the clearing of virus infected cells [20]. Cells undergo apoptosis by either of the activation of caspase cascades that begins from the level of cell surface death receptors, or by the activation of mitochondria followed by release of cytochrome c. L Thyrell et al. showed that IFN- $\alpha$ induces apoptosis and/or CCA in malignant cells, activates several caspases, both the initiator cas-pases- 8 and -9 , the effector caspase- 3 , and caspases- 1 and -2 to induce apoptosis which correlated with a loss of mitochondrial membrane potential $\left(\Psi_{\text {mito }}\right)$ and a release of cytochrome $\mathrm{c}$ into the cytoplasm, whereas the inhibition of the caspases resulted in significantly reduced apoptosis[21]. Hopefully, through Emad technology [22-31] of advanced cellular mechanics in addition to what have been introduced about the molecular IFN- $\alpha$ biological background will prompt further exploration into the mechanism(s) of action of IFN- $\alpha$ and thus introduce new optimizing applications for this prototypic cytokine, whose full therapeutic potential is yet to be realized.

\section{Methods and Materials}

As conducted and described by C. Wang et al [17]; Bone marrow (BM) samples were obtained with informed consent from a previously untreated $\mathrm{Ph}$ chromosome positive newly diagnosed six patients with CML in chronic phase and six normal donors. Heparinized BM samples were collected to prepare mononuclear cells (MNC) of density of, $1.077 \mathrm{~g} / \mathrm{mL}$ by centrifugation in Percoll (Pharmacia Fine Chemicals, AG, Uppsala, Sweden). MNC were washed twice in Iscove's Modified Dulbecco's Medium (IMDM, Gibco, Grand Island, NY) containing $10 \%$ heat-inactivated fetal calf serum (FCS) (Sigma Chemical Inc., St. Louis, MO). T lymphocytes were removed using a second Percoll gradient after rosetting with neuraminidase-treated sheep red blood cells (SRBC) (Woodlyn lab, Guelph, Canada) at $4^{\circ} \mathrm{C}$. The T-cell depleted fraction of MNC was washed twice in IMDM supplemented with $10 \%$ FCS. Thereafter, it was cultured in $75 \mathrm{~mL}$ tissue culture flasks (Nunclon, Life Technologies, Burlington, Canada) in a volume of $4 \mathrm{~mL}$ at a density of 1.5 $\times 10^{6}$ cells per $\mathrm{mL}$ for patient with $\mathrm{CML}$ and $2 \times 10^{6}$ cells per $\mathrm{mL}$ for normal BM specimens. Cells were incubated in IMDM containing 20\% FCS, 50mM 2-mercaptoethaonoal (Sigma Chemical Inc.), $2 \mathrm{mM}$ glutamine (Gibco), $200 \mathrm{ng} / \mathrm{mL}$ granulocyte-macrophage colony-stimulating factor (GM-CSF; Schering Canada Inc, Quebec, Canada), 10 $\mathrm{ng} / \mathrm{mL}$ tumor necrosis factor-alpha (TNF- $\alpha$; Amgen Canada Inc, Mississauga, Ontario, Canada) and $200 \mathrm{ng} / \mathrm{mL}$ interleukin-4 (IL-4) (Schering Canada Inc, Quebec, Canada).
IFN- $\alpha$ (Schering Canada Inc.) was added at the time of culture initiation at doses of $5,50,250$, and $500 \mathrm{U} / \mathrm{mL}$ respectively. DC cultures were maintained at $37^{\circ} \mathrm{C}$ in humidified air supplemented with $5 \% \mathrm{CO}_{2}$. One-third volume of fresh cytokine-supplemented medium without IFN- $\alpha$ was added every 3 to 4 days. After a culture period of 14 days, cells were harvested for cytochemical staining, flow cytometric analysis and MLR assay. MLR cultures were initiated using as targets freshly prepared allogeneic SRBC-separated CML-Patient peripheral blood derived T lymphocytes at a constant number of $5 \times 10^{4}$ cells. Cultured DC were irradiated with 3000 cGy and added at concentrations of $5000 \mathrm{CD} 1 \mathrm{a}^{+}$cells per well as determined by flow cytometry. MLR were initiated in $96 \mathrm{U}$-shaped microtiter wells (Nunclon, Life Technologies, Burlington, Canada) with IMDM supplemented with $10 \%$ FCS. After 5 days, culture wells were pulsed with $1 \mu \mathrm{Ci}$ of Tritiated thymidine $\left({ }^{3} \mathrm{H}-\mathrm{TdR}\right)$ for 18 hours. ${ }^{3} \mathrm{H}-\mathrm{TdR}$ uptake was measured by liquid scintillation counting (LS6000SC, Beckman, Fullerton, CA). Fluorescence in situ hybridization (FISH) analysis was performed to quantify the frequency of bcr-abl DC in fresh samples were obtained with informed consent from newly diagnosed patient with CML in chronic phase with cultured DCs in the absence of IFN- $\alpha$ (control sample) and in the presence of IFN- $\alpha$ at dose $250 \mathrm{U} / \mathrm{mL}$.

Independent observers disagreed by no more than $3 \%$, and background levels were no higher than $4 \%$ in agreement with the specifications for this probe set (Vysis STATE CAT No. 32-190022). The independent t-test was used to evaluate MLR data for the fresh samples with the cultured CML-DC in the presence of the different doses of IFN- $\alpha$. The paired t-test was used to statistically assess flow cytometric and FISH data for differences in cultures with and without IFN$\alpha$.

\section{Results and Analysis}

As conducted and described by C. Wang et al [17]; The total number of cells after 14 days of culture in all samples decreased compared to the initial total number of cells and the number of DC as well. Addition of IFN- $\alpha$ to these cultures resulted in a dose-dependent reduction of cells (caused apoptosis). Recovered DC number for each sample was determined on day 14 of culture and shown in table (1), where data were presented as means of six independent experiments. In FISH analysis, a decrease in the corresponding percentages of the bcr-abl DC signal in those cultures is shown in table (1) which is statistically significant at $p \leq 0.001[17]$.

Table 1 shows fractions of recovered DCs from CML cultured samples after 14 days, data are presented as means of six independent experiments. 
Table 1. also shows the reduction observed in the percentage of bcr-abl $(\mathrm{p} \leq 0.001)$

\begin{tabular}{|c|c|c|c|c|c|}
\hline IFN- $\alpha$ dose & $0 \mathrm{U} \mathrm{m} / \mathrm{L}$ & $5 \mathrm{U} \mathrm{m} / \mathrm{L}$ & $50 \mathrm{U} \mathrm{m} / \mathrm{L}$ & $250 \mathrm{U} \mathrm{m} / \mathrm{L}$ & $500 \mathrm{U} \mathrm{m} / \mathrm{L}$ \\
\hline Fractions of recovered DCs of CML Samples out of $6 \mathrm{~mL}$ & $1.4 \mathrm{~mL}$ & $1.0 \mathrm{~mL}$ & $0.9 \mathrm{~mL}$ & $0.85 \mathrm{~mL}$ & $0.8 \mathrm{~mL}$ \\
\hline $\begin{array}{c}\text { Fractions of recovered DCs of Normal Samples out of } 8 \\
\mathrm{~mL}\end{array}$ & $1.8 \mathrm{~mL}$ & $\begin{array}{c}1.27 \\
\mathrm{~mL}\end{array}$ & $0.97 \mathrm{~mL}$ & 0.65 & $0.485 \mathrm{~mL}$ \\
\hline \begin{tabular}{c} 
Percentage of the bcr-abl DC \\
\hline
\end{tabular} & $48 \%$ & & $29 \%$ & \\
\hline
\end{tabular}

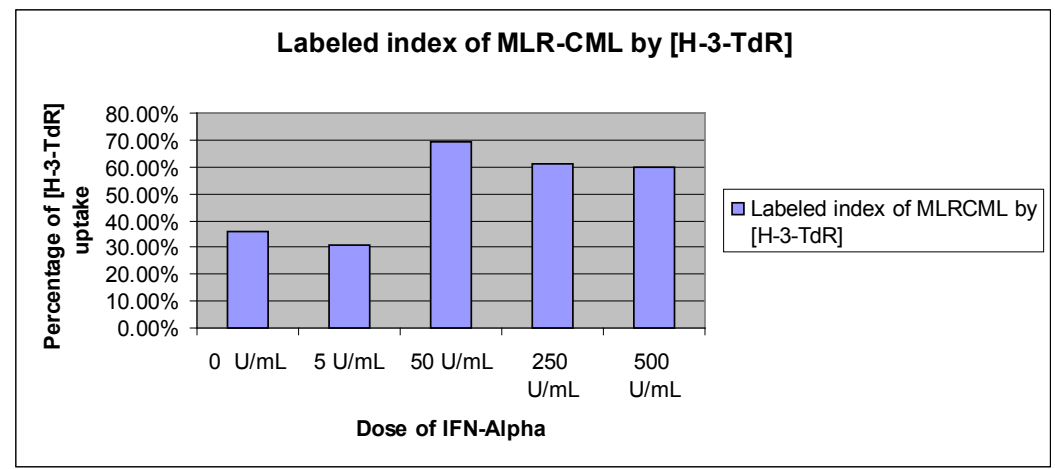

Figure1. shows that addition of IFN-alpha enhanced the stimulatory effect of CML derived DC as shown from the labeled index of MLR cultures by $[\mathrm{H}-3-\mathrm{TdR}](\mathrm{p} \leq 0.001)$.

As shown in table (1) Fractions of recovered DCs of CML samples out of $6 \mathrm{~mL}$ was more than that of Normal samples out of $8 \mathrm{~mL}$ by $\frac{\frac{1.4}{6}-\frac{1.8}{8}}{\frac{1.8}{8}} \times 100 \%=3.7 \%$. According to the hypothesis of low levels of DCs in CML patients compared to that of healthy subjects, this increased level of DCs at CML control samples was attributed to proliferation inhibition induced in arrested CML control samples [32]. Accordingly, the proliferation of DC cultured from BM cells from CML patients (DC-CML) of culture without IFN- $\alpha$ was inhibited more than that of corresponding normal (without IFN- $\alpha$ ) by 3.7\%. Accordingly, Cell Cycle Arrest (CCA) and consequently cell doubling time $\left(t_{D}\right)$ of cultured DC-CML sample without IFN- $\alpha$ were increased $3.7 \%$ more than that of the corresponding normal cells at the Natural Background Radiation (NBR) i.e. $t_{\text {D.CML. } 0}=1.037$ $\times \mathrm{t}_{\mathrm{NBR}}=1.037 \times 1.884220083=1.954 \mathrm{Sec}[23,29]$. This $\mathrm{t}_{\text {D.CML.0 }}$ corresponds to DC growth energy $\mathrm{E}_{\text {DCs-CML.IFN- } \alpha .0}=\ln \left(\ln \left(\ln \frac{\ln 2}{1.954}\right)\right)^{2} \times 23234.59=1661$ $\mathrm{MeV}$ according to Emad formula $\left(\left[\mathrm{E}_{\mathrm{Cell}}=\ln \left(\ln \left(\ln \frac{\ln 2}{\mathrm{t}_{\mathrm{D}}}\right)\right)^{2} \times 23234.59 \mathrm{MeV}\right)\right.$ [22-31]. While inhibition to proliferation was reduced in those cultures incubated with $5,50,250$, and $500 \mathrm{U} \mathrm{m} / \mathrm{L}$ of IFN- $\alpha$ in dose dependent manner to $2.6 \%, 2.4 \%, 2.25 \%$, and $2.1 \%$ respectively. Accordingly, the corresponding DC growth energy of those cultured DC-CML samples in the presence IFN- $\alpha\left(\mathrm{E}_{\text {DC-CML.IFN- } \alpha \text {. }}\right)$ were reduced according to Emad formula as follows:

$$
\begin{array}{r}
\mathrm{E}_{\text {DC-CML.IFN- } \alpha .5}=1199 \mathrm{MeV}, \mathrm{E}_{\text {DC-CML.IFN- } \alpha .50}=1083 \mathrm{MeV}, \\
\mathrm{E}_{\text {DC-CML.IFN- } \alpha .250=1023 \mathrm{MeV} \text {, and }} \mathrm{E}_{\text {DC-CML.IFN- } \alpha .500=964} \\
\mathrm{MeV} .
\end{array}
$$

Thus, incubation of cultured DC-CML samples with IFN$\alpha$ caused a reduction in CCA and consequently $\mathrm{E}_{\mathrm{DC} \text {. CML }}$ by $27.8 \%, 34.8 \%, 38.4 \%$, and $41.96 \%$ respectively. While in FISH analysis the grown cultured DC from the patient without IFN- $\alpha$ contained $48 \%$ bcr/abl positive DC, while incubation of DC with $250 \mathrm{U} / \mathrm{mL}$ of IFN- $\alpha$ resulted in a decrease in bcr/abl positive DC to $29 \%$ [17]. Thus, the percentage of the bcr/abl positive DC was decreased by $39.56 \%$ which is $98 \%$ identical to the corresponding percentage of decrease in energy of DC-CML $\left(\mathrm{E}_{\mathrm{DC} . \mathrm{CML}}\right)$ at the same dose of IFN- $\alpha$ (p $\leq 0.001)$.

Thus, it can be concluded that:

$\%$ of decrease in $E_{\text {DC. CML }}=\%$ of decrease in bcr-abl DC(1)

\section{In MLR Assay}

The effects of IFN- $\alpha$ on DC-CML to stimulate the 
proliferation of $\mathrm{T}$ lymphocytes monitored by the uptake of Tritiated thymidine $\left({ }^{3} \mathrm{H}-\mathrm{TdR}\right)$ in all the studied samples are shown in figure $1[17]$.

The fraction of the malignant cells in the MLR cultures can be identified based on the in vitro measuring of cell proliferating of MLR cultures by thymidine incorporation [24-27]. As labeling of cells by [ ${ }^{3} \mathrm{H}$ ] Tritiated thymidine has been commonly used as an indicator of the proliferative capacity of cells [33], conversely the unlabeled fraction (U \%) of those MLR cultures represents the inhibition to proliferation of cells provided that energy of the deficit part ( $U$ \%) of the thymidine dose is equivalent to the energy of that culture ( $\left.\mathrm{E}_{\mathrm{MLR}}\right)$ as shown by Moawad [24, 27]. Accordingly by knowing the percentage of the unlabeled cells (U \%) of the MLR culture then:

$$
\mathrm{E}_{\mathrm{MLR}}=\mathrm{U} \% \times \mathrm{E}_{\text {Thymidine.Dose }} \mathrm{MeV} \text { (2) [24-27] }
$$

where $\mathrm{E}_{{ }^{3} \text { H.Thymidine.Dose }}$ is the released energy of $1 \mu \mathrm{Ci}$ of $\left[{ }^{3} \mathrm{H}\right]$ Tritiated thymidine (half-life time $=12.32$ Years, decay energy $=0.01859 \mathrm{MeV}$ [34]) during the incubation of $18 \mathrm{hr}$ i.e. $\mathrm{E}_{{ }^{3} \text { H.Thymidine.Dose }}=10^{-6} \times 3.7 \times 10^{10} \times$ $\frac{12.32 \times 3.16 \times 10^{7}}{\ln 2} \times\left(1-\mathrm{e}^{\frac{-\ln 2}{12.32 \times 3.16 \times 10^{7}} 18 \times 60 \times 60}\right) \times$ $0.01859=4.45688122 \times 10^{7} \mathrm{MeV}$.

Thus, by measuring $\mathrm{E}_{\mathrm{MLR}}$ as shown in Eqt 2 and calculating $\mathrm{E}_{\mathrm{DC}}$ by Emad formula as previously shown, the histologic grade $(\mathrm{HG})$ of those fresh samples after adding the cultured DC without IFN- $\alpha$ (HG.Control) or with IFN$\alpha$ doses were identified from allogeneic MLR assay as follows:

$$
\mathrm{E}_{\mathrm{MLR}}=\mathrm{H}_{\mathrm{G}}+\mathrm{E}_{\mathrm{DC}}
$$

where $E_{M L R}$ is the total energy of the MLR culture (cultured DC + freshly peripheral blood of CML patient), while $\mathrm{E}_{\mathrm{DC}}$ is the energy of the added DC only before MLR assay.

From Eqt 3, response to IFN- $\alpha$ treatment was identified by comparing HG.Control and $\mathrm{HG}$ as follows:

The induced released energy due to the loss of mitochondrial membrane integrity ( $\Psi_{\text {mito }}$ ) or the energy gained by those samples due to the induced CCA $\left(\mathrm{E}_{\mathrm{CCA}}\right)$ [22-31], and their subsequent change in samples $\mathrm{H}_{\mathrm{G}}$ in either case due to IFN- $\alpha$ treatment would be according to the following model:

$$
\mathrm{E}_{\mathrm{CCA}} \text { or } \Psi_{\text {mito }}=\left|\mathrm{H}_{\mathrm{G} . \text { Control }}-\mathrm{H}_{\mathrm{G}}\right|
$$

If $\mathrm{HG}<$ HG.Control then from Eqt 4 the loss of mitochondrial membrane integrity $\Psi_{\text {mit.CML }}$ is equivalent to: $\Psi_{\text {mit.CML }}=$ HG.Control- HG.

While, if HG.Control $<$ HG then from Eqt 4 the gained energy $\mathrm{E}_{\mathrm{CCA}}$ as a result of $\mathrm{CCA}$ is equivalent to: $\mathrm{E}_{\mathrm{CCA}}=$ HG - HG.Control.

From figure 1, the labelled index (Li) of MLR cultures of 5 $\times 10^{4}$ cells of freshly prepared allogeneic SRBC-separated CML-Patient peripheral blood derived $\mathrm{T}$ lymphocytes added to $5 \times 10^{3}$ cells of cultured DC-CML incubated with $0,5,50,250$, and $500 \mathrm{U} / \mathrm{mL}$ were $36 \%, 31 \%, 69 \%, 61 \%$, and $60 \%$ respectively. Thus by applying Eqt $2, \mathrm{E}_{\mathrm{MLR}}$ values of the treated cultures were $2.85240398 \times 10^{7}$, $3.07524804 \times 10^{7} \quad, \quad 1.38163318 \times 10^{7}$, $1.73818368 \times 10^{7}$, and $1.78275249 \times 10^{7} \quad \mathrm{MeV}$ respectively. By substituting the derived values of $\mathrm{E}_{\mathrm{MLR}}$ and $\mathrm{E}_{\mathrm{CCA}}$ in Eqt 3, the corresponding $\mathrm{HG}$ of the fresh cultures as hypothesized was $2.02191 \times 10^{7}\left(\mathrm{H}_{\mathrm{G} . \text { Control }}\right)$, $2.479785 \times 10^{7}, 8.3655 \times 10^{6}, 1.22155 \times 10^{7}$, and $1.30075 \times 10^{7} \mathrm{MeV}$ respectively. Accordingly, their corresponding gained or released energy $\left(\mathrm{E}_{\mathrm{CCA}}\right.$ or $\left.\Psi_{\text {mit }}\right)$ from Eqt 4 was as follows where the $(-\mathrm{ve})$ sign indicates a loss of energy:

$$
\begin{array}{r}
\mathrm{E}_{\mathrm{CCA} . \mathrm{IFN}-\alpha .5}=4.57875 \times 10^{6} \mathrm{MeV}, \Psi_{\text {mit.IFN }-\alpha 50}=- \\
1.18536 \times 10^{7} \mathrm{MeV}, \\
\Psi_{\text {mit.IFN- } \alpha 250}=-8.0036 \times 10^{6} \mathrm{MeV}, \Psi_{\text {mit.IFN }-\alpha 500}=- \\
7.2116 \times 10^{6} \mathrm{MeV}
\end{array}
$$

Thus, $5 \mathrm{U} / \mathrm{mL}$ dose of IFN- $\alpha$ decreased the capacity of DC-CML to stimulate T lymphocyte proliferation by $22.65 \%$ than DC-CML without IFN- $\alpha$ (control sample $0 \mathrm{U} / \mathrm{mL}$ ), which indicates that low doses of IFN- $\alpha$ may cause CCA more than that of control sample without activating apoptosis. While, other doses of IFN- $\alpha$ of 50,250 and $500 \mathrm{U} / \mathrm{mL}$ increased such capacity by $58.6 \%, 39.58 \%$, and $35.67 \%$ respectively. This increase was not in a dose-dependent manner to show that the increase of IFN- $\alpha$ dose doesn't necessarily lead to further improvement of the patient. Thus, the effect of adding incubated DC-CML with IFN- $\alpha$ to the peripheral blood derived $\mathrm{T}$ lymphocytes samples of CML-Patient may fluctuate between CCA induction and reducing $\mathrm{H}_{\mathrm{G} . \text { Control }}$, where such discrepancy in efficiency depends on the IFN- $\alpha$ dose. The increase in $\mathrm{E}_{\mathrm{CCA}}$ by 5 $\mathrm{U} / \mathrm{mL}$ dose of IFN- $\alpha$ was $99 \%$ identical to that induced by increasing the dose from $50 \mathrm{U} / \mathrm{mL}$ to $500 \mathrm{U} / \mathrm{mL}$ ( $\leq \leq 0.001$ ), which proves that activating the mitochondria wont continue by increasing the IFN- $\alpha$ dose, but alternatively it would be weakened

$$
\left(1.18536 \times 10^{7} \mathrm{MeV} \rightarrow\right.
$$


$\left.7.2116 \times 10^{6} \mathrm{MeV}\right)$ as a result of $\mathrm{E}_{\mathrm{DC}}$ reduction $(1082$ $\mathrm{MeV} \rightarrow 964 \mathrm{MeV}$ ) by increasing IFN- $\alpha$ dose from 50 $\mathrm{U} / \mathrm{mL}$ to $500 \mathrm{U} / \mathrm{mL}$. In the same time, the reduction in $\mathrm{H}_{\mathrm{G}}$ induced by $250 \mathrm{U} / \mathrm{mL}$ of IFN- $\alpha$ shown in MLR assay was $39.58 \%\left(2.02191 \times 10^{7} \mathrm{MeV}\left(\mathrm{H}_{\text {G.Control }}\right) \rightarrow\right.$ $1.22155 \times 10^{7} \mathrm{MeV}$ ) which was $100 \%$ identical to the corresponding percentage of decrease in $\mathrm{E}_{\mathrm{DC}}$ shown in the in vitro generation of $\mathrm{DC}$ from bone marrow mononuclear cells (BMMNC) of CML patients $(1661 \mathrm{MeV} \rightarrow 1023$ $\mathrm{MeV})$ by the same dose $(250 \mathrm{U} / \mathrm{mL})(\mathrm{p} \leq 0.001)$, and was also $100 \%$ identical to the corresponding percentage of decrease in bcr/abl (48\% $\rightarrow 29 \%)$ shown in FISH analysis induced by the same dose $(250 \mathrm{U} / \mathrm{mL})(\mathrm{p} \leq 0.001)$. Such consistency between the results of the three independent presented applications and the perfect correlation $(|\mathbf{r}|=$ 0.99) between each of $\mathrm{E}_{\mathrm{DC}}, \mathrm{H}_{\mathrm{G}}$ and either of $\Psi_{\text {mit }}$ or $\mathrm{E}_{\mathrm{CCA}}$ provides a clear-cut criterion for accepting the hypothesis of our model for staging CML, and strengthens the confidence in the equivalence of the energy of the unlabeled fraction of the Tritiated thymidine in MLR assay $\left(\mathrm{E}_{\mathrm{MLR}}\right.$ ) with the summation of energies of the treated sample of CML patient $\left(\mathrm{H}_{\mathrm{G}}\right)$ and that of the treatment dose $\left(\mathrm{E}_{\mathrm{DC}}\right)(p \leq 0.0001)$ as presented in Eqt 3, and also confirms the equivalence of the energy gained or released ( $\mathrm{E}_{\mathrm{CCA}}$ or $\Psi_{\text {mit }}$ ) with the absolute difference between the histologic grades of the treated sample with cultured DC without IFN- $\alpha\left(\mathrm{H}_{\mathrm{G} . \mathrm{Control}}\right)$ and of those treated with cultured DC in the presence of different doses of IFN- $\alpha$ $\left(\mathrm{H}_{\mathrm{G}}\right)(p \leq 0.0001)$ as presented in Eqt 4 of our model. Thus from the analysis of the presented results, it can be concluded that the optimum dose of IFN- $\alpha$ for cultured DC should satisfy the following condition:

$$
\% \text { of decrease in } \mathrm{H}_{\mathrm{G} . \text { Control }}\left[\% \text { of }\left(\frac{\Psi_{\text {mit }}}{\mathrm{H}_{\mathrm{G} . \text { Control }}}\right)\right]=\%
$$

of decrease in bcr-abl DC $\geq \%$ of decrease in $\left(\mathrm{E}_{\mathrm{DC}}\right)$ (5),

where in such a case, the effect of IFN- $\alpha$ on the cultured $\mathrm{DC}$ in decreasing the frequency of bcr/abl is $100 \%$ identical to the effect of the cultured DC with IFN- $\alpha$ on the fresh samples of CML patients in stimulating $\mathrm{T}$ cells with specific activity against CML cells. Consequently, the effect of IFN- $\alpha$ doses in each of FISH and MLR applications can be estimated by comparing the recovered fractions of the cultured DC-CML with those doses with respect to the counterparts of the cultured DC-Normal without IFN- $\alpha$ as currently clarified and proved .

\section{Discussion}

Little is known about the mechanism of the generation of DC from BMMNC of CML patients [17, 18]. Data of table 1 demonstrates that rates of apoptosis of the cultured DCs whether from CML-patients or normal donors were increased in the presence of IFN- $\alpha$ in dose-dependent manner. Since apoptosis is considered a normal self adaptation process belongs to normal cells of doubling time ranged from that of cells at Natural Background Radiation (NBR) to that of cells at Maximum Tolerated Dose (MTD) only [29]. Accordingly, cells of doubling time longer than that range fail to the spontaneous apoptosis as commonly shared by the malignant cells. Thus, IFN- $\alpha$ acts via restoring the normal range of cell doubling time to undergo the apoptotic process. Consequently, the mechanism of the in vitro generation of $\mathrm{DC}$ from BMMNC of CML patients by clinical reagents is confined in a cycle of three consecutive actions can't occur simultaneously. The first action is to inhibit the proliferation of tumor cells inducing CCA which activates several caspases, both the initiator cas-pases-8 and -9 , the effector caspase- 3 , and caspases- 1 and -2 . The second action is to activate the mitochondria as a self adaptation process to release the cytochrome $\mathrm{c}$ into the cytoplasm loosing its membrane potential exerting direct effects of energy $\Psi_{\text {mito }}$ on CML cells, including the down-regulation of oncogene expression and induction of tumor suppressor genes. While the third action is to complete such adaptation process by reducing CCA and cell tD once again, decreasing the frequency of bcr/abl oncogene and activating cells to undergo apoptosis by the release of pro-apoptotic factors through the PT-pore [26]. Accordingly, rate of apoptosis would be accelerated gradually by the increase of IFN- $\alpha$ dose in dose dependent manner till restoring the normal rates of cell tD and apoptosis [26]. Thus, the presented mechanism of the in vitro generation of DC from BMMNC of CML patients by clinical reagents is strongly support the notion that IFN- $\alpha$ mediated apoptosis involves the mitochondrial pathway by activating a mitochondrial amplification loop of the apoptotic signal for the apoptotic process to occur. Such three cyclic actions were shown also in DC vaccination protocols. For instance, the cultured DC with low dose of IFN- $\alpha(5 \mathrm{U} / \mathrm{mL})$ induced the first action of CCA only $\left(\mathrm{E}_{\mathrm{CCA}}\right)$ raising MLR mixture energy, while cultured DC with dose $50 \mathrm{U} / \mathrm{mL}$ induced the three actions and achieved the best result among other doses which was the greatest release in MLR mixture energy ( $\Psi_{\text {mito.MAX }}$ ). Whereas, DC with the highest applied dose of $500 \mathrm{U} / \mathrm{mL}$ induced a complete cycle of the three actions and then induced the first action $\left(\mathrm{E}_{\mathrm{CCA}}\right.$ ) only of a new incomplete cycle $99 \%$ identical to that induced by the low dose of $5 \mathrm{U} / \mathrm{mL}$. It was possible to correlate perfectly between the in vitro data of patient response to IFN- $\alpha$ therapy to restore normal rate of apoptosis and that of incubated cultured DC with IFN- $\alpha$ 
$(|r|=0.99)$. No responses to therapy were found in those patients whose cultured DC when incubated with IFN- $\alpha$ showed poor rates of increasing apoptosis and enhancing $\mathrm{T}$ lymphocytes stimulation in MLR assays. In contrast, patients receiving benefit from IFN- $\alpha$ therapy were those who are when their cultured DC incubated with IFN- $\alpha$ showed good rates of increasing apoptosis and enhancing $\mathrm{T}$ lymphocytes stimulation in MLR assays [26]. Such great variability reflects their variability in growth rate (tD) propensity for metastasis, or in other words; in their stages and consequently their corresponding grades. The considerable variation in the percentage of labeled cells by thymidine from sample to sample from same patient was perfect correlated to variation in response to therapies in MLR assays, or in other words to variation in energies (grades) of those samples. The progress through measuring cellular kinetics allowed to improve factors must be given prime consideration in evaluating and comparing different therapeutic regimens [22-31]. The anatomic extent to which the CML has been diagnosed is no longer alone the most important factor determining prognosis. Cell tD which expresses the cell proliferative rate is the added prognostic factor considered in the presented model. The longer the tD of CML cell the more CCA accompanied by aberrant genetic variations that increase the frequency of bcr/abl signal from normal rate of $0.0361 \%\left(361 / 10^{6}\right)$ at NBR gradually to drive normal cell to CML starting from MTD at $0.44 \%$ $\left(4400 / 10^{6}\right)$ of bcr/abl frequency. Thus, energy that drives those aberrant genetic variations in the cultures of whether DC-CML $\left(\mathrm{E}_{\mathrm{DC}}\right)$ or in the fresh samples of CML patients without and with IFN- $\alpha\left(\mathrm{H}_{\mathrm{G} . \text { Control }}, \mathrm{H}_{\mathrm{G}}\right)$ can be estimated using either of Emad formula by knowing cell tD of the cultured DC or by knowing bcr/abl frequency of CML patients in FISH analysis, or by staging a mixture of both cultures in MLR assays as shown in the section of "Results and analysis". The objective of our model is the patient histologic grade to provide a simple way by which this information can readily assist in following up treatments of CML and therapeutic decisions. Perfect correlation between factors of the presented model for IFN- $\alpha$ therapy evaluation $\left(\mathrm{E}_{\mathrm{DC}}, \mathrm{H}_{\mathrm{G}}\right.$ and either of $\Psi_{\text {mit }}$ or $\left.\mathrm{E}_{\mathrm{CCA}}\right)$ confirms, provides a clear-cut criterion for accepting the hypothesis of CML staging, and leaves no room for doubt to predict patient's response to IFN- $\alpha$ therapy.

\section{Conclusion}

The efficiency of IFN- $\alpha$ in DC generation from BMMNC of CML patients and in decreasing the frequency of bcr/abl in the cultured DC is $100 \%$ identical to the efficiency of the cultured DC with IFN- $\alpha$ on the fresh peripheral blood of CML patients in stimulating $\mathrm{T}$ cells with specific activity against CML cells. Energy of the cultured DC-CML ( $\mathrm{E}_{\mathrm{DC}}$ ), percentage of bcr/abl reduction, and histologic grades (HG.Control, HG) derived from MLR assays are the prognostic determinants to identify the maximum $\Psi_{\text {mito }}$ which is the most important determinant helps to administer the most appropriate dose and affects choices and planning for IFN- $\alpha$ treatment. Accordingly, patient-specific approaches that account for HG variations should enable optimal dose estimates. Hereby current approach suggests establishing more suitably clinical vaccination protocols of IFN- $\alpha$ for CML patients in which assessment of dose should be patient-specific to overcome IFN- $\alpha$ resistance.

\section{Conflict of interest}

The author declares that there is no conflict of interest concerning this paper

\section{REFERENCES}

[1] Kurzrock, R., Gutterman, J. U. \& Talpaz, M. (1988) N. Engl. J. Med. 319, 990-998.

[2] Clarkson, B. \& Strife, A. (1993) Leukemia 7, 1683-1721

[3] McGahon, A., Bissonnette, R., Schmitt, M., Cotter, K. M., Martin, S. J., Green, D. R. \& Cotter, T. G. (1994) Blood, in press.

[4] Keating, A. (1993) Stem Cells 11 (Suppl. 3) 31-33.

[5] Niesvizky R, Siegel D and Michaeli J. (1993). Blood Rev., 7, $24-33$.

[6] Raza A. (2000). Leuk. Res., 24, 63 -72.

[7] Choudhury A, Gajewski JL, Liang JC, Popat U, Claxton DF, Kliche KO, Andreeff M, Champlin RE (1997) Use of leukemic dendritic cells for the generation of antileukemic cellular cytotoxicity against Philadelphia chromosome-positive chronic myelogenous leukemia. Blood $89: 1133$

[8] Nieda M, Nicol A, Kikuchi A, Kashiwase K, Taylor K, Suzuki K, Tadokoro K, Juji T (1998) Dendritic cells stimulate the expansion of bcr-abl specific CD81 T cells with cytotoxic activity against leukemic cells from patients with chronic myeloid leukemia. Blood 91:977

[9] Eibl B, Ebner S, Duba C, Bock G, Romani N, Erdel M, Gachter A, Niederwieser D, Schuler G (1997) Dendritic cells generated from blood precursors of chronic myelogenous leukemia patients carry the Philadelphia translocation and can induce a CML-specific primary cytotoxic T-cell response. Genes Chromosomes Cancer 20:215

[10] Mannering SI, McKenzie JL, Fearnley DB, Hart DN (1997) HLADR1- restricted bcr-abl (b3a2)-specific CD41 T lymphocytes respond to dendritic cells pulsed with b3a2 peptide and antigen-presenting cells exposed to b3a2 containing cell lysates. Blood 90:290

[11] Herberman RB (1997) Effect of alpha-interferons on 
immune function. Semin Oncol 24(S9):78

[12] de Waal Malefyt R (1997) The role of type I interferons in the differentiation and function of Th1 and Th2 cells. Semin Oncol 24(S9):94

[13] Tsukada N, Aoki S, Maruyama S, Kishi K, Takahashi M, Aizawa Y (1997) The heterogeneous expression of CD80, CD86 and other adhesion molecules on leukemia and lymphoma cells and their induction by interferon. J Exp Clin Cancer Res 16:171

[14] RL Paquette, N Hsu, J Said, M Mohammed, NP Rao, G Shih, G Schiller, C Sawyers, and JA Glaspy (2002) Interferoninduces dendritic cell differentiation of CML mononuclear cells in vitro and in vivo. Leukemia 16, 1484-1489

[15] Vedantham, S., Gamliel, H. \& Golomb, H. M. (1992) Cancer Res. 52, 1056-1066.

[16] Talpaz, M., Kantaijian, H. M., McCredie, K., Trujillo, J. M., Keating, M. J. \& Gutterman, J. U. (1986) N. Engl. J. Med. 314, 1065-1069.

[17] 17.Wang C, Al-Omar HM, Radvanyi L, Banerjee A, Bouman D, Squire J, Messner HA (1999). Clonal heterogeneity of dendritic cells derived from patients with chronic myeloid leukemia and enhancement of their t-cells stimulatory activity by IFN- $\alpha$. Exp. Hematol., 27(7): 11761184.

[18] Gabriele L, Borghi P, Rozera C, Sestili P, Andreotti M, Guarini A Montefusco E, Foa R, Belardelli F (2004). IFN-alpha promotes the rapid differentiation of monocytes from patients with chronic myeloid leukemia into activated dendritic cells tuned to undergo full maturation after LPS treatment Blood, 103(3): 980-987.

[19] Dhingra, K., Kurzrock, R., Kantaijian, H., Baine, R., Eastman, P. S., Ku, S., Gutterman, J. U. \&Talpaz, M. (1992) Leukemia 6, 754-760.

[20] Los M, Herr I, Friesen C, Fulda S, Schulze-Ostho€ K and Debatin KM. (1997). Blood, 90, 3118 -3129.

[21] Lena Thyrell, Sven Erickson, Boris Zhivotovsky, Katja Pokrovskaja, Olle Sangfelt, Juan Castro, Stefan Einhorn and Dan Grander(2002). Mechanisms of Interferon-alpha induced apoptosis in malignant cells. Oncogene 21, 1251 1262.

[22] Emad Moawad. Isolated System towards a Successful Radiotherapy Treatment, Nuclear Medicine and Molecular Imaging (2010) 44:123-136.
[23] Emad Y. Moawad Radiotherapy and risks of tumor regrowth or inducing second cancer. Cancer Nanotechnology (2011) 2:81-93.

[24] Emad Y. Moawad, Clinical and pathological staging of the cancer at the nanoscale, Cancer Nano (2012) 3:37-46.

[25] Emad Y. Moawad, Reconciliation between the clinical and pathological staging of cancer. Comp Clin Pathol. 2012; DOI: $10.1007 / \mathrm{s} 00580-012-1603-6$.

[26] Emad Y. Moawad, Administering the optimum dose of L-Arginine in regional tumor therapy. Ind J Clin Biochem. 2013; DOI: $10.1007 / \mathrm{s} 12291-013-0379-\mathrm{Z}$

[27] Emad Y. Moawad. Induction of Multiple Sclerosis and Response to Tyrosine Kinase Inhibitors, Ind J Clin Biochem. 2013; DOI: $10.1007 / \mathrm{s} 12291-013-0387-\mathrm{z}$

[28] Emad Y. Moawad, Optimizing Bioethanol production through regulating Yeast Growth Energy, Syst Synth Biol (2012) 6:61-68

[29] Emad Y. Moawad (2013). Nuclear Transmutation and Cancer in the Biological Cell.International Journal of Biochemistry and Biophysics , 1, 1-8. doi: 10.13189/ijbb.2013.010101.

[30] Emad Y. Moawad (2013). Growth Energy of Bacteria and the Associated Electricity Generation in Fuel Cells. Bioengineering and Bioscience, 1, 5 - 10. doi: 10.13189/bb.2013.01010

[31] Emad Y. Moawad (2013). Safe Doses and Cancer Treatment Evaluation. Cancer and Oncology Research, 1 , 6 - 11. doi: 10.13189/cor.2013.010102.

[32] Rickmann M, Krauter J, Stamer K, Heuser M, Salguero G, Mischak-Weissinger E, Ganser A, Stripecke R (2011) Elevated frequencies of leukemic myeloid and plasmacytoid dendritic cells in acute myeloid leukemia with the FLT3 internal tandem duplication. Ann Hematol. doi:10.1007/s00277-011-1231-2

[33] Larry M. Lieb and Hermann Lisco, In Vitro Uptake of Tritiated Thymidine by Carcinoma of the Human Colon, Cancer Res 1966;26:733-740.

[34] Kenneth Barbalace. Periodic Table of Elements - H Hydrogen. EnvironmentalChemistry.com. 1995 - 2011. Accessed on-line: 12/21/2011 http://EnvironmentalChemistr y.com/yogi/periodic/H-pg2.html 